\title{
US scientific panels Bush-whacked
}

In recent months, the United States Department of Health and Human Services (DHHS) has dismantled and re-assembled several of its scientific advisory panels. Although a few scientists allege there are increasing signs that the administration is selecting new committee members based on their political ideology, the vast majority are choosing to stay mum.

There are more than 250 committees and panels that advise the President on scientific issues, either directly, or indirectly by reporting to the DHHS. Complaints about partisanship have dogged the Bush administration since its early days, when it nominated Leon Kass, known for his conservative views on embryonic stem cell research, to head the Council on Bioethics.

More recently, the DHHS overhauled two committees: the Secretary's Advisory Committee on Genetic Testing, which advised the Food and Drug Administration on how to regulate genetic testing, and a committee that examined the health effects of exposure to various pesticides and herbicides.

The DHHS also replaced members of the Advisory Committee on Blood Safety and Availability, previously led by bioethicist Arthur Caplan. "The new blood committee, unlike its predecessor, is very docile when it comes to challenging industry, government regulators and powerful blood collection agencies such as the Red Cross," says Caplan. "Science is usually above politics, but that era is coming to an end."

The latest scuffle involves Jonathan Moreno, director of the University of Virginia's Center for Biomedical Ethics, who declined to serve as a member of the DHHS's new Secretary's Advisory Committee on Human Research Protection (SACHRP). Moreno says that one reason he refused to serve on the committee was the recent introduction of the term 'embryo' into the committee's charter.

Last summer, the DHHS eliminated the National Human Research Protections Advisory Committee (NHRPAC), of which Moreno was a member, and replaced it with the SACHRP. In October, DHHS
Secretary Tommy Thompson signed the new charter, expanding the committee's scope to include embryos and fetuses as human subjects with research protection rights.

"The DHHS included the term embryo into the charter without asking the opinion of researchers or the public," says Moreno. Because the committee advises the DHHS on interpreting federal rules that apply to all research, both federal and private, that is performed in the United States,

including the opinions of patient advocates, was even being considered by the new committee," he says. According to Moreno, no one from the DHHS ever attended a committee meeting before revising the charter, even though they were invited. "The administration doesn't care about human research subjects-all it cares about is bringing embryos and fetuses into the picture," he says.

Many prominent scientists, including members of the National Academy of Sciences, declined to discuss the politicization of DHHS scientific advisory boards. "I don't know why other scientists don't speak out about this," Moreno told Nature Medicine. "I guess it's because it is very prestigious to be on these committees."

Scientists were more vocal when Bioethics Council members were appointed last year. In a New England Journal of Medicine

"these rules could eventually be used to control stem cell research."

According to the new charter, federal rules that apply to research on pregnant women have been changed to separate the interests of the woman from those of the fetus. "This is manipulating the advisory process to get to a certain political endpoint," Moreno says. "Someone in the administration knows that the human research protection framework could be a backdoor way to control stem cell research."

DHHS officials say the charter was expanded to include populations that have traditionally been overlooked. "We used the terms 'pregnant women', 'embryos' and 'fetuses' to cover all terms used in relation to pregnancy," says Bill Pierce, a spokesperson for Secretary Thompson. "We were simply trying to make the charter more inclusive."

But Moreno maintains the committee is being used politically. "I didn't see any indication that the work that the NHRPAC had already done, such as advances we had made in improving informed consent and editorial last May, Irving Weissman pointed out that unlike the panels of the National Academies, whose members pledge to maintain objectivity until all rel-

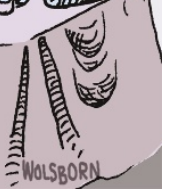

evant data and information have been received and discussed, several members of the Bioethics Council continued to speak and write publicly opposing embryonic stem cell research.

In all fairness, it is often difficult to find committee members that have never spoken out on politically charged issues, notes Gary Borisy, past president of the American Society for Cell Biology. "I don't think it's unethical to appoint an individual to a committee [who] has gone on the record about their thinking on certain issues," he said. "But committee members should be selected who are willing to debate and change their minds about issues, and go beyond their published opinions."

There is no denying that a pro-life, probusiness agenda now dominates scientific committees, says Caplan. "Obviously all administrations tend to fill their advisory boards with people of their own political viewpoint," he says. "But they usually tend to do it less with committees that advise them on scientific, technical, or certainly medical subjects."

Kris Novak, San Francisco 